\title{
A ATUAÇÃO PEDAGÓGICA DO MAGISTRADO NA BUSCA DE UM PROCESSO JUSTO E DE UMA PRESTAÇÃO ADEQUADA: PROTAGONISMO JUDICIAL
}

\author{
THE PEDAGOGICAL PERFORMANCE OF THE JUDGE IN THE SEARCH \\ FOR A FAIR TRIAL AND AN ADEQUATE PROVISION: JUDICIAL ROLE
}

\author{
Elaine Harzheim Macedo ${ }^{1}$ \\ Marina Damasceno ${ }^{2}$
}

\section{RESUMO}

Este trabalho analisa a possibilidade de uma atuação pedagógica por parte do magistrado na busca por um processo justo e adequado. Utilizou, assim, metodologia dedutiva, partindo dos deveres e poderes do juiz para avaliar a possibilidade de induzir condutas pautadas na boa-fé processual mediante a aplicação de litigância de má-fé e determinação de emenda à inicial. $O$ magistrado pode ser um agente que auxilia na efetivação do processo justo e da prestação adequada, não devendo manter-se inerte frente a violações claras aos direitos fundamentais processuais. Essa atividade não deve generalizar as situações, sendo pautada na análise de casos concretos.

Palavras-chave: protagonismo judicial; atuação pedagógica; processo justo.

\begin{abstract}
This work analyzes the possibility of pedagogical performance of the judge in the search for a fair trial and adequate process. Using deductive methodology, starts with the duties and powers of the judge to assess the possibility of inducing practices based on the good faith by applying bad faith litigation and determination of initial amendment. The judge can be an agent that helps in the implementation of fair trial and adequate provision and should not remain inert in relation to clear violations of fundamental procedural rights. This activity should not generalise situations, being based on the analysis of specific cases.
\end{abstract}

Keywords: judicial role; pedagogical performance; fair trial.

\footnotetext{
${ }^{1}$ Doutora em Direito pela Unisinos. Professora catedrática adjunta permanente da Pontifícia Universidade Católica do Rio Grande do Sul na graduação, mestrado e doutorado. Desembargadora aposentada.Advogada. Presidente do IGADE.

${ }^{2}$ Mestranda em Direito pela PUCRS. Bolsista vinculada ao CNPq. Advogada.
} 


\section{INTRODUÇÃO}

A influência dos princípios e direitos fundamentais na jurisdição e no processo tem se mostrado uma tendência concreta, que corresponde à efetiva realização da ordem constitucional e dos direitos e garantias que ela consagra, tornando-se efetivamente o vetor normativo que constitui e organiza uma sociedade. Corroborando com essa ideia, o Código de Processo Civil de 2015 trouxe em seus doze primeiros artigos normas fundamentais, por vezes apropriando-se do texto constitucional e, em outras, explicitando-as. Tais normas fundamentais permeiam todo o remanescente conteúdo do Código, seja na concepção dos respectivos textos, seja na interpretação dos respectivos dispositivos processuais.

Uma das indagações que se põe é como aqueles que atuam no processo devem conduzir-se na realização de tais fundamentos. O questionamento se mostra útil tanto àqueles que intervêm como partes e interessados na solução do conflito ou como seus representantes profissionais, quanto aos órgãos auxiliares da justiça, sejam servidores, sejam peritos, e, por certo, o juiz.

Em meio a isso, o juiz, na função de órgão do Poder Judiciário, detém uma gama de deveres e de poderes que deve ser sopesada ao efeito de, a uma, não aniquilar o protagonismo das partes, que atuam no processo sob o manto do contraditório forte e substancial, característica que acentua a democratização do processo; a duas, guardar uma pró-atividade determinante, tudo com vistas à prestação jurisdicional tempestiva e efetiva. O contraditório, por exemplo, em sua ideia de direito de influência, a representar a efetiva participação na condução do processo e na solução do caso pelas partes, não prescinde de um juiz ativo que propicie os meios necessários para que as partes tenham a oportunidade, de fato, de influir no convencimento jurisdicional.A busca por um processo justo e adequado é dever de todos os que integram o processo.

Cabível ressaltar que um dos motivos para a indevida ou insuficiente prestação jurisdicional é uma atuação pautada no desrespeito aos princípios processuais por meio de uma conduta antiética dos procuradores das partes ou das próprias partes.Nessas situações, o magistrado pode atuar com um viés pedagógico, com a outorga do mandato popular que a sua investidura no cargo, nos termos da Constituição, lhe assegura, 
retomando a condução e o ritmo do proceder, sancionando os excessos, impondo condutas, corrigindo os desvios. Mas esse agir, necessário e indispensável ao bom andamento do processo, deve guardar a devida proporcionalidade entre a dimensão doequívoco e a postura adequada, guardando uma nota mais pedagógica, de inclusão e de participação, sempre objetivando à reconstrução do bom agir processual.

É sabido que a utilização da determinadas condutas podem coibir comportamentos impróprios ${ }^{3}$. O juiz, dessa forma, deve-se utilizar de instrumentos capazes de represar uma conduta antiética, a qual não se coaduna com um processo justo e adequado, mas, ao mesmo tempo, estimular a boa participação, a contribuição que cada um pode, na sua medida, dar para o desiderato último que representa a prestação jurisdicional.

Destarte, utilizando uma metodologia dedutiva ${ }^{4}$, partindo-se de uma definição de processo justo e adequado, bem como de um panorama sobre os deveres e poderes do juiz, serão, após, analisados dois mecanismos que podem contribuir com a atuação pedagógica do magistrado: a aplicação de multa por litigância de má-fé e a possibilidade de determinar a emenda da inicial para afastar argumentos vazios ou infundados. $\mathrm{Na}$ análise de casos concretos, a pesquisa limitou sua abrangência ao Tribunal de Justiça do estado do Rio Grande do Sul.

\section{A BUSCA POR UM PROCESSO JUSTO E ADEQUADO}

O devido processo legal está previsto no inciso $\mathrm{LIV}^{5}$ do artigo $5^{\circ}$ da Constituição Federal, sendo considerado um direito fundamental. Seu caráter aberto traz consigo uma série de outros direitos fundamentais e princípios aplicados ao processo.

Ao realizar uma análise dos direitos fundamentais, é possível atribuir-lhes duas dimensões: subjetiva e objetiva. A primeira noção relaciona-se com a possibilidade do titular de um direito fundamental impor judicialmente seus interesses juridicamente

\footnotetext{
${ }^{3}$ No Direito Tributário, por exemplo, há a figura na extrafiscalidade, na qual o tributo deixa de ter uma finalidade meramente fiscal (ou seja, arrecadatória) e é utilizado como uma forma de dissudiar ou estimular determinadas condutas (PAULSEN, 2012). Por exemplo, aumentar o imposto sobre determinado produto considerado prejudicial à saúde para desincentivar seu consumo.

${ }^{4}$ Segundo Orides Mezzaroba e Cláudula Servilha Monteiro, o referido método inicia com argumentos gerais para chegar a argumentos particulares (2014).

5 Art. $5^{\circ}[\ldots]$ LIV - ninguém será privado da liberdade ou de seus bens sem o devido processo legal;
} 
tutelados perante seu destinatário. Cabível ressaltar que tal grau de exigibilidade varia de acordo com a normatividade de cada direito fundamental (SARLET, 2015, p. 158$160)$.

A perspectiva objetiva, por sua vez, transcende a perspectiva subjetiva, reconhecendo funções e conteúdos normativos distintos aos direitos fundamentais. Traz, assim, uma série de pressupostos, tais como: normas de competência negativa aos poderes públicos, na defesa do indivíduo contra o Estado. Assim, o Estado exerce seu poder dentro do espaço que lhe é determinado. Da mesma forma, há uma ordem dirigida ao Estado visando à concretização e à realização permanente de direitos fundamentais. Não se pode deixar de lado que os direitos fundamentais são utilizados como balizadores nas interpretações das leis e demais atos normativos estatais(SARLET, 2015 , p. $150-153)$.

Voltando à análise do conteúdo do referido direito, cabível situar sua origem histórica. O primeiro ordenamento a referi-lo foi a Magna Carta de João Sem Terra, em 1215, mas não houve menção expressa ao termo. A nomenclatura foi utilizada pela primeira vez mais de meio século após, em 1354, no Statute of Westminster of the Liberties of London(NERY JÚNIOR, 2016, p. 107).

Em razão da origem, alguns autores criticam a utilização do termo "devido processo legal" pela Constituição Federal. Nesse sentido, Luiz Guilherme Marinoni e Daniel Mitidiero afirmam que tal nomenclatura remeteria ao Estado de Direito. O Estado Constitucional, por seu turno, busca a colaboração na realização da tutela efetiva dos direitos mediante a organização de um processo justo (não um devido processo legal). Ademais, não haveria a necessidade de concebê-lo em sua dimensão substancial (2015, p. 730).

Outros autores, contudo, não visualizam o processo justo como uma nova roupagem do devido processo legal, mas o último como um caminho a ser trilhado na direção da decisão justa e, consequentemente, de um processo justo. Nessa linha, Sérgio Luiz Wetzel de Mattos explica:

O direito fundamental a um processo justo compreende, portanto, o direito a um processo legal, porém, informado por direitos fundamentais, especialmente direitos fundamentais processuais, como, por exemplo, o contraditório e ampla defesa, o juiz natural, a igualdade das partes, o direito à prova, etc (2009, p. 174). 
Ainda que se concorde com essas premissas, o fato é que o referido direito fundamental, além de ser entendido como uma cláusula geral que engloba todas as garantias fundamentais do processo, remetendo, assim, ao acesso à jurisdição e à organização do procedimento, carece de mais uma qualificação, isso é ser competente, ser eficiente para alcançar e produzir uma decisão adequada às nuanças do conflito submetido ao Judiciário, que deve agregar as cláusulas da tempestividade e da efetividade. A adequação é, pode-se dizer, a cereja do bolo. De nada adianta garantir-se pleno acesso à jurisdição, contraditório e ampla defesa, procedimento e produção probatória, se a decisão final e compositória do conflito não for adequada à dimensão e características próprias e inerentes desse mesmo conflito, não for apta para sua efetiva e tempestiva superação.

Para que se concretize o processo justo e adequado, é necessário, de um lado, que esse seja regido por todas as garantias englobadas pelo devido processo legal, e, de outro, quiçá, o que mais revela, a produção de uma prestação jurisdicional adequada. Nesse sentido, consolidando-se a perspectiva objetiva do processo justo e adequado, emite-se, diretamente da Constituição, uma ordem a ser concretizada pelo Estado.

Processo justo e adequado é o processo capaz de efetivamente compor os conflitos revestindo-se de todos os direitos e garantias constitucionais, subjetivos ou coletivos, individuais ou sociais.

Para a efetivação do processo justo e adequado, pode-se trabalhar, além de várias outras hipóteses, com a ideia da atuação pedagógica do magistrado, o qual, de maneira pró-ativa, busca influenciar e orientar um comportamento por parte dos jurisdicionados pautados nos princípios processuais.

\section{DEVERES E PODERES DO JUIZ}

O Código de 2015 dedica um capítulo para os poderes, deveres e responsabilidades do juiz, cumprindo aqui, aos objetivos deste trabalho, explorar não dogmaticamente, mas como fundamento para a proposta do agir pedagógico do juiz, em que consiste esses poderes e deveres. 
O ponto fundamental é o art. $2^{\circ}$ da Constituição republicana, que deve ser compreendido sob o enfoque do parágrafo único do art. $1^{\circ}$ : a soberania em todas as suas dimensões - Legislativo, Executivo, Judiciário - pertence ao povo. A Constituição pátria consagra, pois, a soberania popular. Os agentes que, na forma da Constituição, receberão, por delegação, o poder soberano para sua execução, exercem verdadeiros mandatos populares, cuja outorga pode variar entre o voto, a nomeação, a investidura por concurso público, conforme a própria Constituição determinar. Mas, na essência, prossegue sendo mandato. E mandato outorgado pelo povo.

De sorte que antes de se falar em "poder", há que se falar em "dever": o juiz, como mandatário da soberania popular, cumpre um dever que deve ser resguardo pela força do poder sob pena de absoluto esvaziamento da função que lhe é atribuída. Avaliar, portanto, o exercício desse dever-poder é também analisar sua legitimidade, sob pena de arrostar o Estado democrático de Direito (MACEDO, 2012, p. 134).

Conforme dispõe o art. 139, num extenso rol de atribuições entregues ao magistrado, muitas estão atreladas diretamente às normas fundamentais e às garantias constitucionais, tais como assegurar a paridade de armas; velar pela tempestividade processual; preservar a boa-fé processual e reprimir atos contrários à dignidade da justiça; qualificar os comandos decisionais de efetividade; estimular a autocomposição dos conflitos. Outros comandos são voltados para questões procedimentais, tais como os referentes aos prazos processuais; à produção probatória, seja a requerida pelas partes, seja a determinada de ofício; ao poder de polícia; à observância de normas cogentes que dizem com a existência e validade do processo, no cuidado com os pressupostos processuais e saneamento do processo; ao diálogo entre possíveis demandas individuais repetitivas e eventual ação coletiva.

Por certo que tais deveres e poderes são, na essência, exemplificativos, não se podendo afirmar que toda a atividade do magistrado esteja devidamente abarcada por tais dispositivos, ainda queesses se mostrem bastante amplos e genéricos.

Não se pode olvidar, porém, que a atuação do juiz é marcada pela carga interpretiva, pautando-se pela hermenêutica, o que vem destacado pelo art. 140, que reproduz texto da Lei de Introdução às Normas do Direito Brasileiro, conforme destacado por Angelo Maraninchi Giannakos: 
$\mathrm{O}$ art. 140 incorporou a ideia sedimentada de que a lei em sentido estrito é apenas uma das fontes do direito, sendo que a tarefa hermenêutica consiste na interpretação de todo o sistema ou ordenamento jurídico, mas não significa o desprezo às regras ou ao direito legislado, pois tal postura implicaria sério prejuízo ao valor segurança jurídica, o que deve ser evitado (2015, p. 151).

Ou seja, na condução do processo e na prolação da sentença, o juiz trabalhará com as normas constitucionais, com as normas fundamentais do processo, com as disposições infraconstitucionais tanto de natureza processual como material, o que deverá ser interpretado num processo hermenêutico profundamente criativo, com adequação aos fatos que colorem o conflito.

Aqui a indagação: estaria nas atribuições - deveres e poderes - do juiz uma atitude mais pedagógica, mais estimuladora ao bom processo? Afina-se com uma resposta afirmativa, embora isso não signifique que a postura a ser adotada seja paternalista ou didática, o que seria uma afronta ao processo democrático. Não. O juiz ao observar que os direitos processuais fundamentais estão sendo objeto de distorção, de mau uso, de desvios que vão afetar diretamente não só o curso do processo, mas a própria decisão final, irrelevante se por má-fé ou por desconhecimento técnico do profissional, deve coibir tais comportamentos indevidos, enquadrando o processo no justo e adequado espaço que tanto a Constituição como o CPC cuidam de regular. Apenas a título de exemplo, o art. 142, que prevê hipótese agudizada, onde ambas as partes atuam maliciosamente, e que dispõe:

Convencendo-se, pelas circunstâncias, de que o autor e réu se serviram do processo para praticar ato simulado ou conseguir fim vedado por lei, o juiz proferirá decisão que impeça os objetivos das partes aplicando, de ofício as penalidades da litigância de má-fé (BRASIL, 2015).

No âmbito desta previsão, a atitude pedagógica se apresenta com forte caráter sancionador, considerando a gravidade do comportamento adotado por ambas as partes. O mesmo se dá quando a requerimento da parte ou de ofício, for reconhecida a litigância de má-fé, praticada por um dos integrantes do processo, que é tratada no capítulo dos deveres das partes e de seus procuradores, arts. 77 a 81 do novo Código.

Por vezes, porém, a orientação judicial é menos gravosa e mais corretiva, acentuando-se o papel pedagógico. São inúmeras as situações que deixam transparecer 
tal orientação, tais como emenda da petição inicial (art. 321), indeferimento de quesitos formulados pela parte na produção de prova pericial em razão de sua inadequação (decorrência do art. 464, $\S 1^{\circ}$, e do princípio de quem pode mais, pode o menos), correção de ofensa aos pressupostos processuais (art. 76), bem como correção de vícios nos recursos (art. 932, parágrafo único).

Conduzir o processo e compor o conflito de interesses é função de Estado, e, consequentemente, dever-poder do juiz, em que a eficiência deve permear o agir jurisdicional, permitindo que o juiz contribua diretamente pela qualificação de todo agir processual, interferindo diretamente sempre que necessário a assegurar esse desiderato.

\section{O MAGISTRADO COMO INDUTOR DE CONDUTAS}

Conforme abordado anteriormente, o desenvolvimento do processo deve estar atrelado ao respeito dos princípios constitucionais e processuais, bem como pautado na ética. A boa-fé foi eleita como cláusula do bom direito, o que tanto permeia a legislação civil como a legislação processual. Cidadania e dignidade da pessoa humana não combinam com práticas ilícitas e maculadas pela má-fé.

A má advocacia, contudo, atrapalha e prejudica o andamento de um processo justo e adequado - cabível ressaltar que não se quer generalizar, pois é conhecida a atitude ética da significativa maioria dos advogados -, focando-se aqui nas exceções: os que exercem uma advocacia precária e não somente os advogados, porque a má-fé por vezes decorre da própria parte, do sedizente titular do direito subjetivo posto em causa que a todos ilude.

Nessas situações, o magistrado, ao conduzir o processo, é figura essencial na coibição de comportamentos contrários às diretrizes do devido processo legal. Deve atuar de forma pedagógica, induzindo à conduta de boa-fé processual, estimulando-a.

Assim, serão destacados no decorrer deste trabalho dois instrumentos fornecidos pela lei processual e que auxiliam o magistrado em sua atuação pedagógica: a possibilidade de determinar a emenda à inicial e a aplicação de litigância de má-fé.

\subsection{Emenda à inicial}


O artigo 321 do Código de Processo Civil, seguindo a mesma linha do Código anterior, possibilita ao juiz determinar ao autor a emenda da inicial, em decorrência de não estarem preenchidos os pressupostos da exordial ou em havendo defeitos (e irregularidades) capazes de dificultar o julgamento do mérito.

Uma hipótese bastante comum, a qual pode ser considerada um defeito, é a má delimitação do pedido com argumentos demasiados que não se relacionam propriamente ao mérito da questão e transformam as petições em impressos (ou documento eletrônicos) gigantescos, repletos de citações, ementas e argumentos desnecessários ao deslinde da lide.

É necessária, assim, “a restrição da cognição judicial às questões que dizem respeito à tutela do direito é fundamental para a adequada proteção do direito material e para a efetividade do direito fundamental de ação" (MARINONI; ARENHART; MITIDIERO, 2015, p. 141). O magistrado deve ter a possibilidade de identificar toda a matéria que pode ser discutida.

Nesse sentido, o Tribunal de Justiça do estado do Rio Grande do Sul criou o projeto "petição 10, sentença 10"6, apoiado por outras entidades, desincentivando petições e sentenças de extensão exagerada, as quais geram dificuldade na análise do direito controvertido. Propõe, dessa forma, um limite de dez páginas de extensão, visando à qualidade em detrimento da quantidade.

Ressalta-se que não necessariamente uma petição longa gerará dificuldade na questão a ser analisada. Afinal, há questões que, dada a sua complexidade, devem ser melhor explanadas; a situação deve ser verificada caso a caso.

O magistrado, utilizando-se da emenda à inicial, tem a possibilidade de determinar à parte que delimite melhor o direito controvertido, retirando ementas desnecessárias - e por vezes contraditórias entre si ou divorciadas das circunstâncias específicas do caso sub judice - e os argumentos que só servirão de floreios. É um modo de coibir tal postura por parte dos procuradores dos jurisdicionados. Por fim, quando o advogado tem ciência que sua petição não será aceita de pronto pelo juiz, ao menos, refletirá sobre a possibilidade de ajuizar uma ação nesses moldes.

\footnotetext{
${ }^{6}$ Disponível em: <https://www.tjrs.jus.br/site/peticao10sentenca10/sentenca.html>. Acesso em: 28 jun. 2016.
} 
Mas mais do que isso o juiz pode contribuir para que a emenda venha mais precisa e adequada, atendendo com precisão à exigência judicial, especificando em seu despacho o que efetivamente entende como deficiente. Ainda que a regra de fundamentação (art. 489 e seu $\S 1^{\circ}$ ) seja exigida tão somente para as decisões (interlocutórias, sentenças ou acórdãos), nela não se enquadrando a determinação de emenda, o fato é que esse despacho deve orientar a parte sobre os pontos negativos da petição inicial e quais deles estão carentes de aperfeiçoamento, de adequação, de implementação, pelo menos na ótica do magistrado e de sua atuação interpretativa da petição vestibular.

A simples advertência para que o autor emende a inicial nos termos do art. 319 não coaduna com o processo democrático. Aliás, não é por outra razão que o art. 321, autorizador da emenda, em sua parte final expresse: (...) indicando com precisão o que deve ser corrigido ou completado. Trata-se de substancializar nos limites da lide o que a petição inicial não atende adequadamente.

\subsection{A fundamentação também obriga a inicial}

É possível argumentar sobre a impossibilidade do juiz atuar de forma pedagógica no momento de análise da petição inicial em razão do crescimento exponencial no número de processos, impossibilitando uma avaliação aprofundada no recebimento da inicial. $\mathrm{O}$ argumento não procede e deve ser fortemente rechaçado.

Ora, o $\$ 1^{\circ}$ do artigo 489 do Código de Processo Civil trabalha com a ideia da fundamentação das decisões judiciais e o que não poderia ser considerado uma fundamentação adequada. Um dos incisos destaca para a necessidade de todos os argumentos deduzidos no processo capazes de infirmar a conclusão adotada pelo julgador.

Os argumentos vazios, que dificultam o exame do direito a ser tutelado no processo, prejudicando a defesa e praticamente inviabilizando uma sentença adequada. Buscando-se fugir de tais situações, no momento de prolação da sentença, há a possibilidade de afastá-los no momento de recebimento da inicial.

Adiantar o momento de delimitação dos argumentos que sustentam de fato a lide permite um desenvolvimento da demanda mais direcionado ao processo justo e 
adequado e, consequentemente, à decisão precisa, eficiente, amoldada ao caso concreto. E mais, permite a defesa do demandado, pois a inépcia ou a simples aglomeração de teses e argumentos desconectados não autoriza defesa adequada, prejudicando o réu no processo.De outra banda, além de facilitar no momento da fundamentação da sentença, auxilia na delimitação das questões a serem objeto de prova. Ademais, uma petição com demasiadas páginas e arguições vazias implica em uma peça de defesa que enfrente todos os argumentos - a situação transforma-se em uma "bola de neve".

E o Código processual de 2015 inovou significativamente nesse sentido, a exemplo da improcedência liminar do pedido (art. 332); da extinção parcial de pedidos formulada na fase do julgamento conforme o estado do processo (art. 354, parágrafo único); do julgamento antecipado parcial do mérito (art. 356).

De sorte que também na fase do recebimento da petição inicial, cumpre, numa atuação tipicamente pedagógica, o juiz sanear, delimitar, excluir fundamentos de fato ou de direito que não se coadunem com a demanda posta.

Essa providência pode ser tomada mediante a determinação de emenda da inicial, ao efeito de melhor esclarecer a parte autora quais são os fatos e fundamentos de seu(s) pedido(s), aplicando-se-lhe também o dever de fundamentação, o que decorre diretamente do art. 319, incisos III e IV. Sem dúvida que o processo seguirá seu rumo de forma mais justa e adequada, se tais providências forem adotadas quando a petição inicial mostra-se abusiva, mal preparada, comungando das mais diversas teses por vezes até inconciliáveis e afastando-se da concretudo do conflito.

\subsection{A aplicação de litigância de má-fé}

De uma forma harmônica, o art. $77^{7}$ do Código de Processo Civil enuncia deveres das partes, de seus procuradores e de quaisquer intervenientes no processo, o

\footnotetext{
${ }^{7}$ Art. 77. Além de outros previstos neste Código, são deveres das partes, de seus procuradores e de todos aqueles que de qualquer forma participem do processo: I - expor os fatos em juízo conforme a verdade; II - não formular pretensão ou de apresentar defesa quando cientes de que são destituídas de
} 
qual deve ser compreendido com o art. $80^{8}$ do mesmo estatuto, que, por sua vez, traz um rol de hipóteses em que é possível verificar um comportamento de litigância de má-fé por parte do autor, réu ou intervenientes. Caso comprovada a situação, é aplicável multa, bem como indenização pelos prejuízos e despesas sofridos.

A litigância de má-fé configura, dessa forma, abuso do direito, resultando na responsabilidade pelos atos processuais realizados em dissonância com a proibidade processual e implicando o dever de ressarcir. Ressalta-se que, para sua caracterização, é imprescindível o elemento subjetivo, ou seja, agir com dolo ou culpa grave (OLIVEIRA, 2000, p. 34).

Quanto ao dano e à condenação, Ana Lúcia Iecker Meirelles de Oliveira defende que, embora a legislação não cite diretamente a ocorrência de danos morais em tais casos, o principal dano ocorrente é esse. Ademais, como a indenização por dano moral tem caráter dúplice, a condenação por litigância também teria caráter sancionador e indenizador. A multa, a seu turno, seria penalidade pura e simples (2000, p. 34).

João Batista Lopes, por sua vez, defende impropriedade na redação do artigo 18 do Código de Processo Civil de 1973 (atualmente, artigo 80), porque o legislador não fez distinção entre e penalidade e indenização. O magistrado, entretanto, ao aplicar de ofício a litigância, somente poderia fazê-lo em relação à penalidade - a indenização se restringiria aos casos em que suscitada pela outra parte (1997, p. 128).

No que tange a condenações mais severas relacionadas ao ato, Paola Roos Braun (2013) defende a possibilidade de retirada do benefício da justiça gratuita quando houver condenação por litigância de má-fé. A manutenção colocaria em conflito todo o sistema, por atentar contra dimensão ética e contra a probidade que o processo e o Direito, como um todo, pressupõe. E complementa:

fundamento;III - não produzir provas e não praticar atos inúteis ou desnecessários à declaração ou à defesa do direito;IV - cumprir com exatidão as decisões jurisdicionais, de natureza provisória ou final, e não criar embaraços à sua efetivação; $\mathrm{V}$ - declinar, no primeiro momento que lhes couber falar nos autos, o endereço residencial ou profissional onde receberão intimações, atualizando essa informação sempre que ocorrer qualquer modificação temporária ou definitiva;VI - não praticar inovação ilegal no estado de fato de bem ou direito litigioso.

8 Art. 80. Considera-se litigante de má-fé aquele que: I - deduzir pretensão ou defesa contra texto expresso de lei ou fato incontroverso; II - alterar a verdade dos fatos; III - usar do processo para conseguir objetivo ilegal; IV - opuser resistência injustificada ao andamento do processo; V - proceder de modo temerário em qualquer incidente ou ato do processo; VI - provocar incidente manifestamente infundado; VII - interpuser recurso com intuito manifestamente protelatório. 
A possibilidade de litigar amparado no benefício da gratuidade da justiça - sem necessidade de arcar com despesa processual de qualquer natureza e nem preocupar-se com ônus de sucumbência acaba sendo estimulo à propositura de demandas que não passam de aventurar jurídicas (BRAUN, 2013).

A busca por um processo justo e adequado não se mostra efetiva quando os jurisdicionados e seus procuradores agem contra princípios processuais basilares, como a boa-fé. A boa-fé é uma dimensão subjetiva da dignidade da pessoa humana, permeando todo o ordenamento jurídico. O magistrado, dessa forma, deve interferir coibindo condutas nesse sentido e aplicando as sanções cabíveis.

A penalidade, assim, não tem apenas um caráter punitivo, mas também pedagógico, de maneira a represar que comportamentos ímprobos assolem a construção de uma decisão justa. Não pode o juiz ter receio de aplicar as medidas de coibição e muito menos de adotar a sanção adequada, proporcional ao deslize.

Quanto à possibilidade de retirada do benefício da gratuidade de justiça, parece ser cabível a aplicação, uma vez que o acesso à justiça deve ser realizado com responsabiliade. Contudo, nessas situações, a análise do caso concreto deve ser minuciosa, porquanto a parte, muitas vezes, é ignorante em relação ao comportamento desonesto de seu procurador e será a principal prejudicada pela afastamento do referido benefício.

E mais, especificando a hipótese de litigância de má-fé caracterizada como inovação ilegal no estado de fato de bem ou direito litigioso, conforme previsto no inciso VI do art. 77, antes referido, o legislador destacou que tal comportamento constitui ato atentatório à dignidade da justiça, prevendo paralelamento que seus reflexos podem alcançar a esfera criminal e civil, além da processual, autorizando não só a cominação de pena pecuniária $\left(\S 2^{\circ}\right)$, passível de execução de dívida ativa $\left(\S 3^{\circ}\right)$, como a emissão de comando cominatório, restabelecendo-se o estado anterior, e, o que mais revela, o mandamento de proibir a parte de falar nos autos até a purgação do atentado, o que pode ser cumulativo à sanção pecuniária $\left(\S 7^{\circ}\right)$.

A proibição de falar nos autos mostra-se significativamente pedagógica, porque cerceia a parte infratora de prosseguir se manifestando no processo, isso porque praticou ato de inovação ilegal no estado de fato, induzindo o juízo a erro no seu mister de conduzir o processo e decidir o conflito. É pedagógica não só porque evitar o prosseguir 
no agir malicioso, mas também impõe correção do ilícito, recompondo o restabelecimento do estado anterior.

Litigância de boa-fé, como dever da parte, e litigância de má-fé, como sanção e resgate do bom processo, estão intimamente conectados com a eficiência do processo justo e adequado.

\subsection{Os Tribunais e a aplicação da litigância de má-fé}

No momento de aplicação da litigância de má-fé, não basta que o magistrado de primeiro grau atue de maneira pedagógica aplicando as penalidades e indenizações cabíveis. O Tribunal, em caso de recurso, deve manter a autoridade da decisão do juízo a quo, respeitados casos excepcionais em que resta clara a aplicação desmedida da litigância.

Ao avaliar a jurisprudência do Tribunal de Justiça do estado do Rio Grande do Sul, verifica-se certa resistência por parte dos desembargadores em manter ou atribuir a litigância de má-fé. Nesse sentido, cabível a breve análise de dois julgados do referido Tribunal, que embora não represente numericamente a posição, não deixam de ser paradigmáticos.

O primeiro acórdão deixou de atribuir multa de litigância de má-fé à parte que utilizou a ação rescisória como forma de sucedâneo recursal, pois essa hipótese não estava prevista no rol do artigo 17 do Código de Processo Civil de 1973 (atualmente, artigo 80). O réu demonstrou que o autor da referida ação utilizou-se das mesmas razões já exaustivamente rebatidas no julgamento da causa. Colaciona-se abaixo a ementa do julgado:

AÇÃO RESCISÓRIA. AÇÃO DE RESCISÃO CONTRATUAL. VIOLAÇÃO LITERAL DE LEI E ERRO DE FATO INOCORRENTES. RESCISÓRIA UTILIZADA COMO SUCEDÂNEO RECURSAL. ART. 485, V E IX, DO CPC/1973. DESCABIMENTO. 1. A ação rescisória, por constituir medida excepcional, que visa a atacar decisão transitada em julgado, somente admite juízo de procedência se configurada uma das hipóteses taxativas que a lei processual prevê. 2. Ação rescisória - manejada em face de aresto que manteve a sentença proferida em ação de rescisão de contrato - utilizada como sucedâneo recursal, veiculando inequívoca pretensão de mero reexame da causa ou de revaloração 
probatória, não merece prosperar. Alegações de violação literal de lei e erro de fato inexistentes. 3.Litigância de má-fé não verificada, uma vez que não configurada quaisquer das condutas processuais elencadas no art. 17 do CPC/1973. Ação rescisória improcedente. Unânime. (Ação Rescisória No 70062934013, Décimo Grupo de Câmaras Cíveis, Tribunal de Justiça do RS, Relator: Voltaire de Lima Moraes, Julgado em 24/06/2016).

Analisando o voto proferido pelo relator, condutor da unanimidade, foi comprovada a tentativa do autor da ação rescisória de utilizá-la como recurso, desviando a finalidade da demanda, a qual, apenas em casos excepcionais e justificados, flexibiliza a estabilidade da coisa julgada no ordenamento jurídico. Uma interpretação mais ampliativa do rol do artigo 80 poderia enquadrar essa situação como litigância de má-fé, em hipótese de incidente infundado, por exemplo.

A mesma resistência em aplicar as referidas sanções, pode ser analisada em apelação, julgada por outro órgão fracionário do mesmo Tribunal, o qual deu provimento parcial à apelação apenas para retirar a litigância de má-fé atribuída pelo magistrado de $1^{\mathrm{o}}$ grau em sentença. Conforme ementa:

Apelação cível. Ação de rescisão contratual. Contrato de locação com opção de compra. Preliminares afastadas. Mérito. Ocorrência da coisa julgada. CPC, art. $301, \S \S 1^{\circ}, 2^{\circ}$ e $3^{\circ}$. Descabimento da penalidade por litigância de má-fé. Apelo parcialmente provido. (Apelação Cível $\mathrm{N}^{\circ}$ 70066389867, Décima Terceira Câmara Cível, Tribunal de Justiça do RS, Relator: Breno Pereira da Costa Vasconcellos, Julgado em 28/01/2016)

A ação de primeiro grau foi extinta pela ofensa à coisa julgada. A magistrada aplicou litigância de má-fé, uma vez que a demandante ajuizou nova ação para ver rescindido o contrato que já fora extinto, a fim de receber de volta o valor superior aos $\mathrm{R} \$$ 2.000.000,00 que foram reconhecidos na decisão transitada em julgado, em favor da parte ré (em reconvenção) e que foram objeto de compensação já operada.

A provocação do Poder Judiciário pela parte foi manifestamente infundada, além de demonstrar clara vontade da demandante em beneficiar-se da própria torpeza, hipótese de litigância de má-fé, em especial no previsto pelo art. 77 , inciso II do CPC/2015.Contudo, o tribunal, no exercício do reexame, afastou a penalidade, mantendo, porém, no mais a sentença de primeiro grau. 
Os números de casos julgados, por óbvio, não se esgotam nos dois exemplos colecionados, mas tais exemplos geram uma reflexão, frente a uma tendência dos tribunais em minimizar as sanções processuais, desmotivando os magistrados de primeiro grau a serem mais rígidos, mais sancionadores, aplicando as regras processuais de litigância de má-fé.

Questiona-se, assim, se o magistrado não se sentiria desmotivado em sua atuação pedagógica, visto que, provavelmente, não surtiria qualquer efeito, dado o histórico de reformas das penalidades por parte do Tribunal.

Por certo que tal indagação exigiria uma outra pesquisa a ser produzida em trabalho próprio, mas ainda assim pertinente ao âmbito do que ora se proõe, qual seja, a conduta ou o agir pedagógico dos magistrados - irrelevante se de primeiro ou de segundo grau - no afã de contribur para a concretização de um processo justo e adequado.

\section{CONSIDERAÇÕES FINAIS}

Com vistas a um processo justo, ou seja, um processo cujo desenvolvimento foi pautado em princípios processuais e constitucionais, e adequado - isso é, capaz de concluir com uma decisão que corresponda a uma prestação jurisdicional efetiva e tempestiva - o juiz pode atuar de forma pedagógica, em função da perspectiva objetiva do direito fundamental ao devido processo legal. Essa atuação visa a coibir condutas dos jurisdicionados e seus procuradores que violem algum princípio basilar do processo. Como mecanimos para essa atividade do magistrado, foram destacadas ferramentas processuais bem precisas e reguladas em capítulo próprio do Código de Processo Civil de 2015: a determinação de emenda à inicial e a aplicação de litigância de má-fé.

No caso da emenda à inicial, o magistrado pode determinar, além dos vícios que desqualificam a petição, no momento do recebimento da petição, que o autor retire toda a argumentação desnecessária que possa gerar dificuldade na análise do direito controvertido. Frisa-se, nesses casos, que a fundamentação também obriga a inicial, possibilitando adiantar a análise dos argumentos vazios no início do processo e sua exclusão do devido processo. 
A litigância de má-fé visa também a coibir condutas ilícitas, com sanções pecuniárias, com comandos mandamentais de agir processual e culminando, inclusive com a possível perda do benefício da gratuidade de justiça, sempre priorizando a análise do caso concreto. O magistrado não pode ter receio de aplicar tais penalidades e indenizações, cumprindo com o seu dever jurisdicional de bem conduzir o processo e de proferir sentença capaz de efetiva e tempestivamente compor o conflito.

Além de uma postura ativa do magistrado na luta contra a má-fé processual, o Tribunal, ao analisar recursos e proferir decisões, também ocupa espaço importante e central, visto que deve manter a autoridade da decisão do juiz, exceto em casos excepcionais, nos quais foi aplicada de forma desmedida. Nesse sentido, ao analisar exemplificativamente julgados do Tribunal de Justiça do Estado do Rio Grande do Sul, é possível identificar uma certa resistência dos julgadores de segundo grau em manter e aplicar o sancionamento previso em lei, numa atitude de leniência no mínimo desconfortável ao bom processo.

Desse modo, percebe-se claramente a possibilidade de o magistrado atuar de forma pedagógica, induzindo condutas positivas e coibindo condutas negativas por parte dos jurisdicionados e seus procuradores. Frisa-se que, para alcançar o processo justo e adequado, também é necessária uma atuação conjunta do Poder Judiciário, por todos os seus órgãos.

\section{REFERÊNCIAS BIBLIOGRÁFICAS}

BRAUN, Paola Roos. A manutenção da gratuidade judiciária em caso de condenação por litigância de má-fé: uma incompatibilidade. In: MAILLART, Adriana Silva; COSTA, Suzana Henriques (Org.). XXII Encontro Nacional do CONPEDI: Sociedade global e seus impactos sobre o estudo e a efetividade do Direito na contemporaneidade. 22. ed. Florianópolis: FUNJAB, 2013, p. 474-503.

GIANNAKOS, Angelo Maraninchi. Anotações aos artigos 139 a 143. In:Novo Código de Processo Civil Anotado. MACEDO, Elaine Harzheim; MIGLIAVACCA, Carolina Moraes (org.), Porto Alegre: OAB-RS, 2015, p. 149-154.

LOPES, João Batista. O juiz e a litigância de má-fé. Revista dos Tribunais, São Paulo, v.740, p. 128, jun. 1997. 
MACEDO, Elaine Harzheim. O juiz e o Poder Judiciário do século XXI: considerações sobre a legitimação das decisões. In MITIDIERO, Daniel; AMARAL, Guilherme Rizzo (org.). Processo Civil: estudos em homenagem ao Professor Doutor Carlos Alberto Alvaro de Oliveira, São Paulo: Atlas, 2012, p. 132-155.

MARINONI, Luiz Guilherme; ARENHART, Sérgio Cruz; MITIDIERO, Daniel. O novo processo civil. São Paulo: Revista dos Tribunais, 2015.

MARINONI, Luiz Guilherme; MITIDIERO, Daniel. Direitos fundamentais processuais. In: SARLET, Ingo Wolfgang; ; Curso de direito constitucional. 4. ed. atual. e ampl. São Paulo: Revista dos Tribunais, 2015.

MATTOS, Sérgio Luís Wetzel de. Devido processo legal e proteção de direitos. Porto Alegre: Livraria do Advogado, 2009.

MEZZAROBA, Orides; MONTEIRO, Cláudia Sevilha. Manual de metodologia da pesquisa no direito. 6. ed. São Paulo: Saraiva, 2014.

NERY JÚNIOR, Nelson. Princípios do processo na Constituição Federal. 12. ed. São Paulo: Revista dos Tribunais, 2016.

OLIVERA, Ana Lúcia Iucker Meirelles de. Litigância de má-fé. São Paulo: Revista dos Tribunais, 2000.

PAULSEN, Leandro. Curso de direito tributário completo. 4.ed. Porto Alegre: Livraria do Advogado, 2012.

SARLET, Ingo Wolfgang. A eficácia dos direitos fundamentais: uma teoria geral dos direitos fundamentais na perspectiva constitucional. 12. ed. rev. atual. e ampl. Porto Alegre: Livraria do Advogado, 2015. 